\title{
THE NATIONAL LAND TRANSPORT STRATEGIC FRAMEWORK FOR SOUTH AFRICA (2015) AND RELATED TRANSPORTATION INSTRUMENTS: THE APPLICATION OF TRANSPORTATION MODELLING FOR IMPROVED DECISION MAKING?
}

\author{
ILSE SCHOEMAN \\ Unit for Business Mathematics and Informatics, North West University, South Africa.
}

\begin{abstract}
The National Land Transport Strategic Framework (NLTSF) (2006) in South Africa was reviewed in 2015 in order to address current transportation issues after 21 years in a democratic society. This process was preceded by the publication of the National Development Plan (NDP) (2012) setting new development focuses and more specifically related to development of transportation systems, infrastructure goals and objectives influencing the movement of people, goods and services.

The NDP holds specific implications for the implementation of planning instruments such as the NLTSF, the National Transport Master Plan (NATMAP) and the recently published Integrated Urban Development Framework (IUDF) (2014). If the content of these documents is evaluated, it is clear that it mainly consists of development principles that are uncoordinated and disjointed in terms of transportation development. This holds implications for transportation planning and development in terms of system development, priorities and projects. It focuses spatially on what should be done nationally with restricted intelligence on where it should take place and how development priorities should be determined.

Transportation plans and development without supporting decision-making systems remain the goals and objectives of this study. This article will assess the use and application of decision-making tools through transportation modelling methodologies and practices. It will include the design of a framework to address challenges related to transportation planning through modelling techniques. It will inform decision making in enhancing transportation system and infrastructure development and enable interface management between transportation instruments.
\end{abstract}

Keywords: transport decision making, transportation modelling, transportation planning, urban transport.

\section{INTRODUCTION}

The National Land Transport Strategic Framework (NLTSF) [1] in South Africa was extensively reviewed in 2015 [2] in order to address current transportation issues after 21 years in a democratic society.

The purpose of this article is to assess, relate and illustrate how the transportation and development strategic instruments (i.e. NLTSF [2], National Development Plan (NDP) [3] and National Transport Master Plan (NATMAP) [4]) are being applied in the transformation of the spatial systems and the development of transportation infrastructure projects. In isolation the strategic instruments are subservient to its specific goals and objectives formulated to address certain core issues related to transportation and development. In an endeavour to promote integration between such strategic instruments to guide sustainable movement of people, goods, services and communication, this article addresses the role of transportation modelling in strategic decision making and articulation. The motivation for this article

This paper is part of the proceedings of the 22nd International Conference on Urban Transport and the Environment (Urban Transport 2016)

www.witconferences.com 
follows from the Integrated Urban Development Framework (IUDF) [5] and the challenges stated in the above-mentioned strategic instruments. From IUDF [5] it follows that one of the key challenges at local level is with the monitoring of municipal performance; currently monitoring is incomplete, fragmented without adequate analytical capacity to generate real insight into actual performance and risk management.

\section{STRATEGIC INTEGRATION AND DEVELOPMENT POINTS OF DEPARTURE}

According to Dressler [6], Haberberg and Rieple [7], Parnell [8] and David [9], strategic management serves a variety of purposes in attaining a vision, goals and objectives within an organization (inclusive of the public sector).

Similar strategic and/or fundamental principles support transportation planning and spatial or regional planning (refer to CSIR [10] and Schoeman [11]). The complexities involved in strategic transportation planning are best described by the term CLIOS (complex, large-scale, integrated, open systems) [12]. Robinson [13] points out that business leaders, strategists and scenario planners have drawn attention for some years to the confused and unstructured times we are living in. He states that the roots of the strategic approach and its methodologies can be traced back to literature on warfare, business, political science and operational research. This relates directly to the issues stated in the introduction of this article. From Thompson and Strickland [14] and David [9] it follows that strategy-making and implementation consist of the following six interrelated managerial tasks:

- forming a strategic vision of what the future business makeup will be;

- setting objectives;

- external and internal assessment;

- formulation of a strategy to achieve the desired outcomes;

- implementing and executing the chosen strategy;

- evaluating performance and corrective adjustment to the process.

Jeston and Nelis [15] point out that strategic management depends on process management inclusive of strategic alignment. For the purpose of this study, the interface between strategic management and planning should be considered as well. Litman [16] concludes that planning includes the following principles: to be comprehensive, efficient, inclusive, informative, integrated, logical and transparent. Strategic management thus serves as a building block for sustainable planning.

\section{THE NATIONAL DEVELOPMENT PLAN AS STRATEGIC INSTRUMENT}

The National Development Plan (NDP) 2030 for South Africa [3] endeavours to eliminate poverty and reduce inequality within the country by 2030 . South Africa can only realize identified development goals by building on the energies of its citizens, growing an inclusive economy, building capabilities, enhancing the capacity of the state, and promoting leadership and partnerships throughout society.

The NDP is based on the National Planning Commission's Diagnostic Report [17] of 2011, which contains the achievements and shortcomings since democratization in 1994 within the national spatial system. The NDP identifies the failure to implement policies and concludes that the absence of broad partnerships as the main reasons for slow progress.

The NDP 2030 [3] provides a broad national strategic framework to guide key choices and actions. It identifies challenges and development priorities as shown in Table 1. Of importance to this study is the planned implementation phases of the NDP that underpin the addressing 
Table 1: Development challenges and interventions as included in the National Development Plan (NDP) and the National Infrastructure Plan (NIP) 2012.

\begin{tabular}{|c|c|c|}
\hline $\begin{array}{l}\text { Development challenges } \\
\text { to be addressed }\end{array}$ & Development priorities & $\begin{array}{l}\text { Focus of infrastructural } \\
\text { development }\end{array}$ \\
\hline $\begin{array}{l}\text { - Too few people work. } \\
\text { - The quality of school educa- } \\
\text { tion for black people is poor. } \\
\text { - Infrastructure is poorly } \\
\text { located, inadequate and } \\
\text { under-maintained. } \\
\text { - Spatial divides hobble inclu- } \\
\text { sive development. } \\
\text { - The economy is unsustain- } \\
\text { ably resource intensive. } \\
\text { - The public health system } \\
\text { cannot meet demand or } \\
\text { sustain quality. } \\
\text { - Public services are uneven } \\
\text { and often of poor quality. } \\
\text { - Corruption levels are high. } \\
\text { South Africa remains a } \\
\text { divided society. }\end{array}$ & $\begin{array}{l}\text { - Uniting all South Afri- } \\
\text { cans around a common } \\
\text { programme to achieve } \\
\text { prosperity and equity. } \\
\text { - Promoting active citizenry } \\
\text { to strengthen development, } \\
\text { democracy and account- } \\
\text { ability. } \\
\text { - Bringing about faster } \\
\text { economic growth, higher } \\
\text { investment and greater } \\
\text { labour absorption. } \\
\text { - Focusing on key capabili- } \\
\text { ties of people and the state. } \\
\text { - Building a capable and } \\
\text { developmental state. } \\
\text { - Encouraging strong lead- } \\
\text { ership throughout society } \\
\text { to work together to solve } \\
\text { problems. }\end{array}$ & $\begin{array}{l}\text { - Promote balanced } \\
\text { economic develop- } \\
\text { ment. } \\
\text { - Unlock economic } \\
\text { opportunities. } \\
\text { - Promote mineral } \\
\text { extraction and benefi- } \\
\text { ciation. } \\
\text { - Address socio-eco- } \\
\text { nomic needs. } \\
\text { - Promote job creation. } \\
\text { - Assists in integrating } \\
\text { human settlements } \\
\text { and economic devel- } \\
\text { opment. }\end{array}$ \\
\hline
\end{tabular}

Source: Adapted from Schoeman [11].

of the development challenges and priorities that mainly focuses on social, economic, developmental and infrastructural issues inclusive of safe and reliable public transport. The implementation is divided into broad phases: critical steps to be taken by 2013 to unlock implementation; 2014-2019 planning cycle; 2019-2024 and 2024-2009 planning cycles.

These phases are identified to ensure integration of the NDP into the plans of the various spheres of government and supporting role of different sectors and society. The integration planning of the NDP thus directly relates to the need to translate strategic management processes into planning policies and plans as pointed out above.

The integration planning of the NDP thus directly relates to the need to translate strategic management processes into planning policies and plans as pointed out above. The NDP [3] contains the following objectives:

- an economy that will create more jobs and employment;

- improving and development of infrastructure (including transportation);

- transition to a low-carbon economy;

- an inclusive and integrated rural economy;

- reversing the spatial effects of apartheid;

- improving the quality of education, training and innovation;

- quality health care for all;

- social protection;

- building safer communities; 
- reforming the Public Service;

- fighting corruption;

- enhancing social cohesion.

Zarenda [18] discusses the implications of the NDP for regional development while Van Nieuwkerk [19] deals with the NDP and its foreign policy. The conclusions in these critiques are of value to both the NATMAP [4] and the NLTSF [2] as transportation is fundamental in terms of internalities and externalities as to achieve its goals, objectives and priorities.

\section{THE NATIONAL TRANSPORT MASTER PLAN AS STRATEGIC INSTRUMENT}

In line with the challenges and objectives as given in the NDP [3], the NATMAP [4] of 2011 was updated in 2015 [20] to ensure alignment and integration between the strategic and planning process and focuses involved. In the assessment of the NATMAP-Synopsis Update [20], it should be noted that the alignment was not only focused on the content of the NDP but also on the NLTSF [2]. Both documents NLTSF [2] and NATMAP [20] are examples of the role of the Department of Transport in fulfilling its mandate endeavours to integrate the challenges

Table 2: Strategic objectives, actions and current realities in NATMAP.

\begin{tabular}{|c|c|c|}
\hline Objectives & Actions & Current Realities \\
\hline $\begin{array}{l}\text { An improved sustainable } \\
\text { public transport system. } \\
\text { - Greater mobility options. } \\
\text { - Non-motorized transport } \\
\text { network development. } \\
\text { - A transport system that } \\
\text { promotes better integration } \\
\text { between land use planning } \\
\text { and transport. } \\
\text { - Improved infrastructure and } \\
\text { maintenance. } \\
\text { - A transport system that is } \\
\text { consistent with the real needs } \\
\text { of people living in different } \\
\text { parts of the spatial system. } \\
\text { - A transport system with } \\
\text { charges that reflect real costs. } \\
\text { Development of a transport } \\
\text { system that supports focused } \\
\text { funding of transport priorities. } \\
\text { - A transport system that has } \\
\text { sufficient human capital to } \\
\text { drive the vision of transport. } \\
\text { - A transport system that } \\
\text { enables and supports rural } \\
\text { development. }\end{array}$ & $\begin{array}{l}\text { - Grow the economy. } \\
\text { - Protect the environ- } \\
\text { ment. } \\
\text { - Integrate land use } \\
\text { and transportation } \\
\text { planning. } \\
\text { - Improve public } \\
\text { transport. } \\
\text { - Enhance and } \\
\text { manage infrastruc- } \\
\text { ture. } \\
\text { - Promote safety and } \\
\text { well-being. } \\
\text { - Ensure social inclu- } \\
\text { sion and accessibil- } \\
\text { ity. } \\
\text { - Promote freight } \\
\text { integration. } \\
\text { - Support rural devel- } \\
\text { opment. }\end{array}$ & $\begin{array}{l}\text { - Lack of integrated transport } \\
\text { planning across all modes of } \\
\text { transport. } \\
\text { - Fragmented nature of institu- } \\
\text { tional governance. } \\
\text { - Impact of freight movement on } \\
\text { the road network. } \\
\text { - Road safety accidents are very } \\
\text { severe and high. } \\
\text { - Economic challenges due to } \\
\text { low population densities within } \\
\text { the spatial systems. } \\
\text { - Lack of liveable communities } \\
\text { and high levels of urban migra- } \\
\text { tion. } \\
\text { - Lack of modal integration and } \\
\text { transport hub development. } \\
\text { - Lack of implementation of ex- } \\
\text { isting regulations and policies. } \\
\text { - Problems with adequate fund- } \\
\text { ing availability that can't be } \\
\text { funded by the fiscus alone. }\end{array}$ \\
\hline
\end{tabular}

Source: Own construction from NATMAP [20]. 
and priorities of the NDP [3]. Transportation forms the core of development and without it the challenges in the NDP would have been predominantly idealistic and theoretical in nature (also see report [17]).

Table 2 shows the objectives and actions as identified in the NATMAP [20]. Two core chapters in the NATMAP [20], Chapter 2: "An Aligned \& Integrated Planning Framework" and Chapter 13: "NATMAP 2050 Implementation Methodology" inclusive of a prioritization methodology, an assessment framework, appraisal approach and content (problems and options, capital costs, operating costs, revenue, wider benefits and completion of the appraisal), form the theme of this study. A practical guidance to transport investment in terms of a four stage approach is identified. Key performance indicators are identified for integrated transport planning, public transport, environment, freight transport, infrastructure (road and rail), road safety and rural transport supported by measurement yardsticks and targets are included.

The following delivery and implementation approach is identified:

- Step 1: Define the needs, objectives and strategic case that confirm an issue has to be addressed.

- Step 2: Identify the preferred intervention.

- Step 3: Apply a common basis assessment framework to prioritize interventions/options in meeting transport objectives.

- Step 4: Select the highest ranking option/interventions to be scrutinized in terms of the guidance on transport investment.

- Step 5: Undertake individual business cases for each intervention selected using an appropriate delivery model.

- Step 6: Apply for funding via the National Transport Forum/local partnership or appropriate funding agency.

- Step 7: Secure funding.

- Step 8: Implement project.

- Step 9: Measure the success of the project. Monitor and review.

The above-mentioned approach serves as a guide for decision making. The application thereof is flexible. The model is presented as a point of departure only. Deviations may be

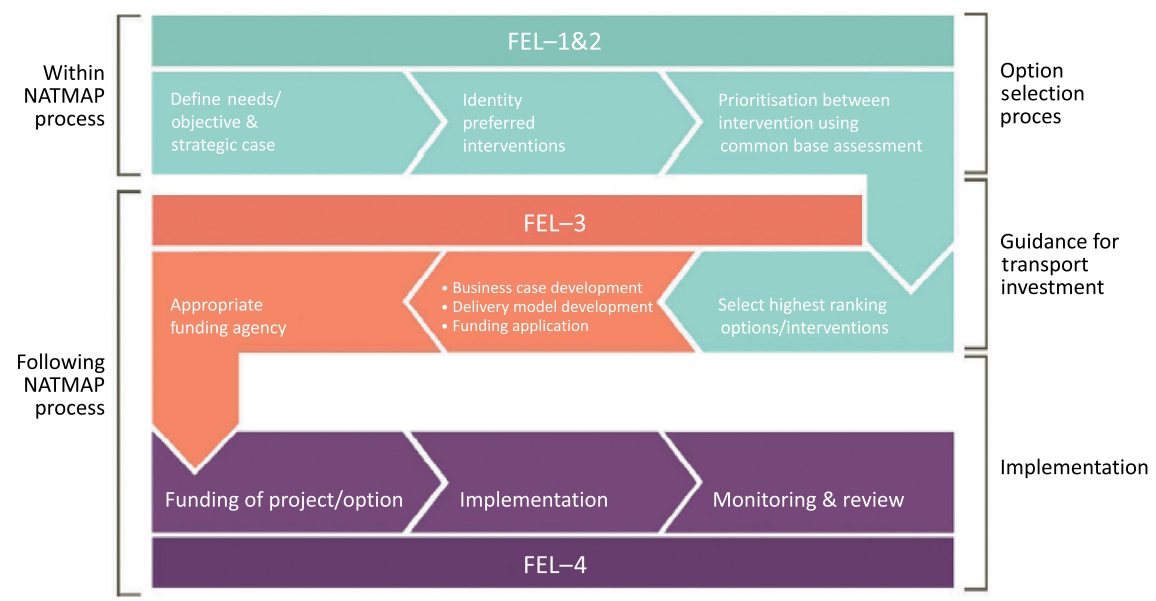

Figure 1: Framework for using the NATMAP model (Source: NATMAP [20]). 


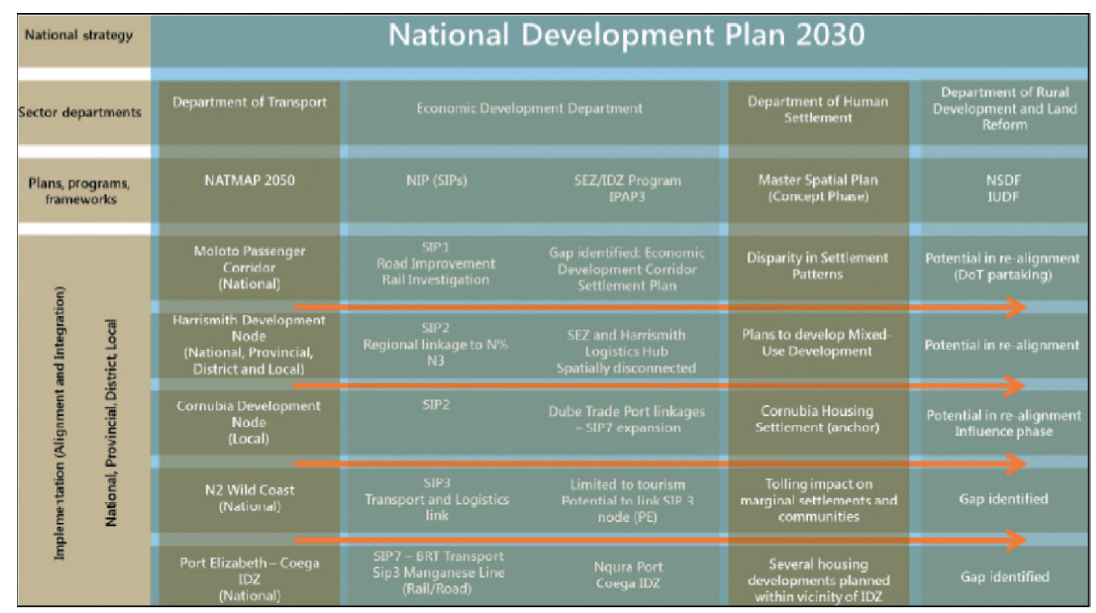

Figure 2: Conclusion matrix demonstrating implementation, alignment and integration in NATMAP [20].

Table 3: Vertical and horizontal integration of the NATMAP model.

\begin{tabular}{|c|c|c|}
\hline \multicolumn{2}{|c|}{ Horizontal integration } & Vertical integration \\
\hline Cross-sectorial & $\begin{array}{l}\text { Transport system } \\
\text { (accessibility and mode) }\end{array}$ & $\begin{array}{l}\text { National Provin- Local } \\
\text { cial }\end{array}$ \\
\hline (1) Housing & (1) Road & \multirow{3}{*}{$\begin{array}{l}\text { (1) Connectivity } \\
\text { Simple gravity model. } \\
\text { Origin, destination patterns } \\
\text { by options. }\end{array}$} \\
\hline (a) Housing density & $\begin{array}{l}\text { (a) Current (\# and } \mathrm{km} \text { of } \\
\text { class } 2-4 \text { level roads). }\end{array}$ & \\
\hline $\begin{array}{l}\text { (2) Employment opportunities } \\
\text { within the project area }\end{array}$ & $\begin{array}{l}\text { (b) Infrastructure needs } \\
\text { (road) }\end{array}$ & \\
\hline $\begin{array}{l}\text { (a) Total area reserved for } \\
\text { economic / industrial } \\
\text { development. }\end{array}$ & (2) Rail & (2) Mobility \\
\hline (3) Social infrastructure & (a) Current (rail services). & (a) Road hierarchy. \\
\hline (a) Densification strategy. & (b) Current (rail capacity). & \multirow{3}{*}{$\begin{array}{l}\text { (b) Current (congestion } \\
\text { levels). } \\
\text { (c) Road traffic regulation } \\
\text { enforcement. }\end{array}$} \\
\hline (b) Educational institutions. & $\begin{array}{l}\text { (c) Infrastructure needs } \\
\text { (rail services). }\end{array}$ & \\
\hline (4) Bulk infrastructure & (3) Public transport & \\
\hline $\begin{array}{l}\text { (a) Estimated cost to address } \\
\text { the backlog in bulk ser- } \\
\text { vices in residential } \\
\text { areas surrounding } \\
\text { project. }\end{array}$ & $\begin{array}{l}\text { (a) Current (public transport } \\
\text { capacity). } \\
\text { (b) Current (public transport } \\
\text { availability). } \\
\text { (c) Infrastructure needs (public } \\
\text { transport services). }\end{array}$ & \\
\hline
\end{tabular}

Source: Own construction from NATMAP [20]. 
required due to the nature and definition of certain projects. Figure 1 shows the logic of this approach.

On an illustrative basis, NATMAP [20] includes maps on national level of an integrated view of its articulation with the National Infrastructure Plan (NIP), NDP, Department of Human Settlements planning, Department of Public Enterprises (DPE) and Department of Trade and Industry (DTI) projects. Figure 2 shows the matrix demonstrating the implementation, alignment and integration as concluded in NATMAP [20].

NATMAP [20] is dynamic in the sense that it provides for a process to integrate vertical policies, vision, etc. of the different spheres of government. It guides the development of transport solutions and applicable technology which are implemented by different spheres of government. The application of the approach is practically applied to the strategic integrated projects (SIPs) in the National Infrastructure Plan (NIP) [21, 22] and the NDP [3]. Table 3 illustrates the alignment evaluation use in NATMAP for the integration between projects and initiatives at national, provincial or local level in terms of planning and implementation. This was used for the alignment of NATMAP with the different SIPs.

\section{NATIONAL LAND TRANSPORT STRATEGIC FRAMEWORK AS STRATEGIC INSTRUMENT}

Table 4 summarizes the content of the NLTSF [2].

The NLTSF [1] was reviewed in 2014/15 by the NLTSF of 2015 [2]. Table 4 refers to the objectives, current realities, actions fields and functional areas included in the NLTSF [2]. Note that the timeframe of the NLTSF is only five years; after five years it will be updated.

As indicated in the title of this article the pivotal point relates to the approach as contained in the NLTSF [2] and its related instruments (discussed above) as a new challenge for transportation modelling in strategic decision making. The NATMAP [20] demonstrates the approach towards integration and alignment from a transportation perspective by articulation of strategic management concepts and principles, objectives and priorities in the NDP [3] and the challenges and current reality guiding transportation planning in the NATMAP [20].

The formulation of this strategic framework focusing on transport is prepared from the perspective of the legal obligation contained in the National Land Transport Act 2009 [23], Section 23. The NLTSF sets out strategic priorities to apply transportation planning in achieving social, health, economic and environmental outcomes. The NLTSF [2] was formulated due to the Public Transport Strategy and Action Plan [24], the NDP [3], Draft Scholar Transport Policy [25] and the NATMAP [20]. The NLTSF [2] of 2015 also includes strategic priorities to apply and outcomes linked to the strategic instruments discussed in this article and aligns to all transportation and spatial planning, strategies and plans of all spheres of government.

In context to the focus of this study, the NLTSF [2] is not a transport strategy or transport plan but a framework for transportation planning in context to the strategic instruments (NDP and NATMAP). It sets from a strategic perspective goals, vision and objectives for components of the transport system included in Provincial Land Transport Frameworks (PLTFs) and Integrated Transport Plans. It contains transportation projects in context to specific formulated Key Performance Areas.

The vision for the NLTSF [2] is: 'An integrated and efficient transport system supporting a thriving economy that promotes sustainable economic growth, provides safe and accessible mobility options, socially includes all communities and preserves the environment'.

The vision is thus well aligned to the NDP [3] and the NATMAP [20] and is illustrative of promoting integration and alignment between all strategic instruments dealt with in this article. 
Table 4: Summary of the core components in the NLTSF.

\begin{tabular}{|c|c|c|c|}
\hline Objectives & Current realities & Actions fields & $\begin{array}{l}\text { Functional areas include } \\
\text { in NLTSF }\end{array}$ \\
\hline $\begin{array}{l}\text { Understanding of } \\
\text { the current transport } \\
\text { realities. }\end{array}$ & $\begin{array}{l}\text { Redundant policy } \\
\text { frameworks and } \\
\text { legislation. }\end{array}$ & Economics. & Transport infrastructure. \\
\hline $\begin{array}{l}\text { Addressing the } \\
\text { gaps in the current } \\
\text { framework. }\end{array}$ & $\begin{array}{l}\text { Inadequate/lack } \\
\text { skilled human re- } \\
\text { sources to implement } \\
\text { policies and legisla- } \\
\text { tion. }\end{array}$ & Environmental. & $\begin{array}{l}\text { Transport: } \\
\text { (a) urban, } \\
\text { (b) rural, } \\
\text { (c) public, } \\
\text { (d) non-motorized, } \\
\text { (e) learner, } \\
\text { (f) freight. }\end{array}$ \\
\hline $\begin{array}{l}\text { Review of NLTSF } \\
\text { in the context of current } \\
\text { national policies and } \\
\text { functional area policy } \\
\text { documents. }\end{array}$ & Limited funding. & $\begin{array}{l}\text { Land use and } \\
\text { Transport } \\
\text { Integration. }\end{array}$ & $\begin{array}{l}\text { Integrated land use and } \\
\text { transportation planning. }\end{array}$ \\
\hline $\begin{array}{l}\text { Literature review of } \\
\text { policy documents, } \\
\text { strategies and plans } \\
\text { relevant to transport. }\end{array}$ & $\begin{array}{l}\text { Intergovernmental } \\
\text { (vertical disjointed } \\
\text { communication and } \\
\text { lack in coordination. }\end{array}$ & $\begin{array}{l}\text { Public } \\
\text { transport. }\end{array}$ & Cross-border transport. \\
\hline $\begin{array}{l}\text { Five-year framework to } \\
\text { integrate land use and } \\
\text { transport. }\end{array}$ & $\begin{array}{l}\text { Inefficient public } \\
\text { transport provision }\end{array}$ & $\begin{array}{l}\text { Social } \\
\text { inclusion and } \\
\text { Accessibility. }\end{array}$ & Transport safety. \\
\hline $\begin{array}{l}\text { Provide guiding } \\
\text { principles that integrate } \\
\text { various modes } \\
\text { of land transport. }\end{array}$ & $\begin{array}{l}\text { Lack of horisontal } \\
\text { integration. Uncoor- } \\
\text { dinated actions and } \\
\text { projects of transport } \\
\text { agencies and opera- } \\
\text { tors. }\end{array}$ & $\begin{array}{l}\text { Safety and } \\
\text { Wellbeing. }\end{array}$ & $\begin{array}{l}\text { Institutional management } \\
\text { incorporating land trans- } \\
\text { port information systems, } \\
\text { Inter- } \\
\text { Governmental relations } \\
\text { and capacity to deliver. }\end{array}$ \\
\hline $\begin{array}{l}\text { Provide clarity } \\
\text { and certainty about } \\
\text { transport planning } \\
\text { priorities to enable } \\
\text { effective decision making. }\end{array}$ & $\begin{array}{l}\text { Lack of consistent } \\
\text { and reliable transport } \\
\text { demand data. }\end{array}$ & $\begin{array}{l}\text { Information } \\
\text { Management } \\
\text { (land-use/ } \\
\text { transportation } \\
\text { database). }\end{array}$ & \\
\hline $\begin{array}{l}\text { To align transport to } \\
\text { sustainable development }\end{array}$ & Conflicting interests. & & Funding. \\
\hline $\begin{array}{l}\text { Support implementation } \\
\text { of NDP. }\end{array}$ & $\begin{array}{l}\text { Competition among } \\
\text { transport modes. } \\
\text { Imbalance in the road } \\
\text { vs. freight modal split. } \\
\text { Poor spatial form. }\end{array}$ & & \\
\hline
\end{tabular}

Source: Own construction from NLTSF [2]. 
Table 5: Indicators to monitor successfulness of policies in modelling.

\begin{tabular}{|c|c|c|c|c|}
\hline Indicators & \multicolumn{4}{|c|}{ Considering the following trends, numbers or ratios. } \\
\hline $\begin{array}{l}\text { Trends in } \\
\text { population } \\
\text { growth and } \\
\text { urbanization }\end{array}$ & $\begin{array}{l}\text { The annual population in } \\
\text { urban agglomerations } \\
\text { ( }>1 \text { million people) }\end{array}$ & $\begin{array}{l}\text { The annual growth } \\
\text { of people in urban } \\
\text { agglomerations ( } \% \\
\text { of total population) }\end{array}$ & $\begin{array}{l}\text { The annual } \\
\text { national popu- } \\
\text { lation growth } \\
\text { rate. }\end{array}$ & $\begin{array}{l}\text { The annual } \\
\text { national popu- } \\
\text { lation growth } \\
\text { rate vs. total } \\
\text { population. }\end{array}$ \\
\hline $\begin{array}{l}\text { Monthly } \\
\text { disposal } \\
\text { income spent } \\
\text { on transport. }\end{array}$ & $\begin{array}{l}\text { National income } \\
\text { profile (2003 and 2013). }\end{array}$ & $\begin{array}{l}\% \text { of monthly } \\
\text { income spent } \\
\text { on transport by } \\
\text { income bracket }\end{array}$ & $\begin{array}{l}\% \text { of monthly } \\
\text { income spent } \\
\text { on transport by } \\
\text { income bracket }\end{array}$ & \\
\hline $\begin{array}{l}\text { Travel } \\
\text { modes. }\end{array}$ & $\begin{array}{l}\text { National modal } \\
\text { split (2003 and 2013) }\end{array}$ & $\begin{array}{l}\text { National public } \\
\text { transport ( } 2003 \\
\text { and 2013) and } \% \\
\text { change. }\end{array}$ & $\begin{array}{l}\text { and per trans- } \\
\text { port mode. } \\
\text { National } \\
\text { scholar trans- } \\
\text { port modal } \\
\text { split (2013). }\end{array}$ & \\
\hline $\begin{array}{l}\text { Travel time } \\
\text { by mode. }\end{array}$ & $\begin{array}{l}\text { Travel time } \\
\text { for different time } \\
\text { intervals) by mode } \\
\text { (2003 and 2013). }\end{array}$ & $\begin{array}{l}\text { Accessibility of } \\
\text { public transport } \\
\text { transport ( } 2003 \text { and } \\
\text { 2013). By walking } \\
\text { time to nearest PT. } \\
\% \text { in different time } \\
\text { intervals. }\end{array}$ & & \\
\hline $\begin{array}{l}\text { Infrastructure } \\
\text { expenditure. }\end{array}$ & $\begin{array}{l}\text { Annual national expendi- } \\
\text { ture on road infrastruc- } \\
\text { ture. }\end{array}$ & $\begin{array}{l}\% \text { of annual } \\
\text { government } \\
\text { expenditure on } \\
\text { infra-structure } \\
\text { relation to benefit } \\
\text { for the car or PT } \\
\text { commuter. }\end{array}$ & & \\
\hline $\begin{array}{l}\text { Green } \\
\text { house gas } \\
\text { emissions. }\end{array}$ & $\begin{array}{l}\text { Annual } \mathrm{CO}_{2} \text { emissions } \\
\text { in relation to housing } \\
\text { consumption levels. }\end{array}$ & $\begin{array}{l}\text { Annual } \mathrm{CO}_{2} \text { emis- } \\
\text { sions in relation } \\
\text { to total number of } \\
\text { vehicles. }\end{array}$ & & \\
\hline $\begin{array}{l}\text { Freight } \\
\text { modal bal- } \\
\text { ance. }\end{array}$ & $\begin{array}{l}\text { The annual surface freight } \\
\text { (rail and trucks) modal } \\
\text { split. }\end{array}$ & $\begin{array}{l}\text { Annual growth in } \\
\text { cross border trade. } \\
\text { Consider growth } \\
\text { in imports and } \\
\text { exports to region } \\
\text { countries. }\end{array}$ & & \\
\hline Road safety. & $\begin{array}{l}\text { RSA (road fatalities } \\
100,000 \text { people) ratio com- } \\
\text { pared with the other coun- } \\
\text { tries in the world ratios. }\end{array}$ & $\begin{array}{l}\text { Annual RSA (road } \\
\text { fatalities/100,000 } \\
\text { people) ratio and } \\
\text { trend. }\end{array}$ & & \\
\hline $\begin{array}{l}\text { Passenger } \\
\text { rail volumes. }\end{array}$ & $\begin{array}{l}\text { Three major Metropoles } \\
\text { daily train volumes per } \\
\text { annum. }\end{array}$ & & & \\
\hline
\end{tabular}

Source: Own construction from NLTSF [2]. 
The interaction between these strategic instruments is as follows: NATMAP supports the implementation of NDP, NIP and NLTSF, but must also be supported by SPLUMA, IUDF, IDF and SDF. The NLTSF, IUDF and SPLUMA support the implementation of the NDP and the NATMAP. Integration of strategic management and spatial and transportation planning process within all spheres of government is much more complicated than only to harmonize and align of policies and plans. It will need articulation in terms of development impact assessment in terms of the diverse needs, standards, prioritization and timeframes for implementation. The application of modelling as a technique to support complex decision making is thus essential from a transportation, infrastructure and development perspective. This forms an important condition to optimize the implementation of the NDP in terms of its limited timeframes and resources base availability.

Key performance areas (KPAs) are developed in the NLSF supported by measurable key performance indicators (KPIs). This will be monitored through the National Transportation Forum (NTF) in assisting the effectiveness of the NLTSF [2] within all spheres of government. Table 5 shows the indicators identified in the NLTSF [2] to determine the extent to which policies and plans have been successful.

The role that transportation modelling plays in the strategic decision-making process is given by the implementation (i.e. the KPAs, KPIs) and prioritization and ways to monitor these policies, strategies, regulations and planning in a sustainable and resilient way. Table 6 follows from the fact that in the NDP the input and output is given in terms of policy, strategy and planning, which is also given in NATMAP but with the add on of national implementation

Table 6: Classification of the input, focus and outcomes included in strategic instruments.

\begin{tabular}{|c|c|c|c|}
\hline $\begin{array}{l}\text { Strategic instru- } \\
\text { ments }\end{array}$ & Articulation & KPAs & $\begin{array}{l}\text { KPI's implementation applicable on munici- } \\
\text { pal sphere }\end{array}$ \\
\hline
\end{tabular}

Journey time to work(door-to-door) by all modes.

Transport model.

Rural access (\%) health facilities.

Quality of roads (pavement condition index).

Traffic network performance(flow rate).

\begin{tabular}{|c|c|c|c|}
\hline $\begin{array}{l}\text { NLTSF I } \\
\text { NATMP I NDP }\end{array}$ & Yes I Yes I Yes & $\begin{array}{l}\text { Integrated } \\
\text { transport }\end{array}$ & $\begin{array}{l}\text { Quality walking links to main public trans- } \\
\text { port nodes in } 20 \mathrm{~min} \text { or } 1 \mathrm{~km} \text { radius. }\end{array}$ \\
\hline
\end{tabular}

Increase commuting to work trips by public transport and walking.

$\%$ of income spend on transport.

Full cycle lane within a radius of $5 \mathrm{~km}$ from main PT nodes.

Increase in proportion of households in rural areas within about $2 \mathrm{~km}$ of a public transport service.

Quality of PT service.

Operations subsidy ( $\mathrm{R} \&$ per $\mathrm{km} \&$ per passenger).

Infrastructure (R). 


\begin{tabular}{|c|c|c|c|}
\hline $\begin{array}{l}\text { NLTSF | } \\
\text { NATMP I NDP }\end{array}$ & Yes I Yes I Yes & $\begin{array}{l}\text { Public } \\
\text { transport }\end{array}$ & $\begin{array}{l}\text { Vehicle utilisation during peak and off-peak } \\
\text { periods. } \\
\text { Contract, operational requirements and per- } \\
\text { formance specifications developed for schol- } \\
\text { ar transport service providers. ( } \% \text { of schools } \\
\text { with reliable access) and (\# of school with } \\
\text { safe non-motorised transport facilities). }\end{array}$ \\
\hline $\begin{array}{l}\text { NLTSF । } \\
\text { NATMP I NDP }\end{array}$ & Yes I Yes I Yes & $\begin{array}{l}\text { Environ- } \\
\text { ment }\end{array}$ & $\begin{array}{l}\text { Greenhouse gas emission from all road - } \\
\text { based transport. } \\
\text { Reduction in overloading by enforcing limits }\end{array}$ \\
\hline $\begin{array}{l}\text { NLTSF । } \\
\text { NATMP I NDP }\end{array}$ & Yes | Yes I Yes & $\begin{array}{l}\text { Freight } \\
\text { transport }\end{array}$ & $\begin{array}{l}\text { Provision of alternative routes for transport } \\
\text { of heavy goods vehicle in urban areas. } \\
\text { NMT (km of read with sidewalk and cycle } \\
\text { lanes).future need (km of sidewalk and } \\
\text { cycle lanes). } \\
\% \text { of budget spend on ITS. }\end{array}$ \\
\hline $\begin{array}{l}\text { NLTSF । } \\
\text { NATMP I NDP }\end{array}$ & Yes | Yes I Yes & $\begin{array}{l}\text { Road infra- } \\
\text { structure }\end{array}$ & $\begin{array}{l}\text { Update strategic road network plan (infra- } \\
\text { structure spend). } \\
\text { infrastructure asset management system } \\
\text { Condition and improvement of classified } \\
\text { road network. }\end{array}$ \\
\hline $\begin{array}{l}\text { NLTSF | } \\
\text { NATMP I NDP }\end{array}$ & Yes | Yes I No & $\begin{array}{l}\text { Road } \\
\text { safety }\end{array}$ & $\begin{array}{l}\text { Reduction in the number of crashes ex- } \\
\text { pressed as the number of people per } 100 \\
\text { million vehicle kilometers }\end{array}$ \\
\hline NLTSF & Yes & $\begin{array}{l}\text { Non- } \\
\text { motorised }\end{array}$ & $\begin{array}{l}\text { Development of complete streets plans } \\
\text { (universal access). }\end{array}$ \\
\hline NATMP & Yes & transport & Increase commuting by cycling. \\
\hline NDP & No & & $\begin{array}{l}\text { Climate impact value of cycling and } \\
\text { walking. }\end{array}$ \\
\hline $\begin{array}{l}\text { NLTSF | } \\
\text { NATMP | NDP }\end{array}$ & Yes/YeslNo & $\begin{array}{l}\text { Learner } \\
\text { transport }\end{array}$ & $\begin{array}{l}\text { Monitor travel behaviour/mode choice of } \\
\text { learners. }\end{array}$ \\
\hline $\begin{array}{l}\text { NLTSF । } \\
\text { NATMP I NDP }\end{array}$ & YesINolNo & $\begin{array}{l}\text { Inter- } \\
\text { government } \\
\text { relations }\end{array}$ & $\begin{array}{l}\text { Turnaround time of approvals, licences, } \\
\text { R.O.D. }\end{array}$ \\
\hline $\begin{array}{l}\text { NLTSF | } \\
\text { NATMP I NDP }\end{array}$ & YeslYeslNo & Database & $\begin{array}{l}\text { Updated GIS based Land Transport Informa- } \\
\text { tion System. }\end{array}$ \\
\hline $\begin{array}{l}\text { NLTSF | } \\
\text { NATMP I NDP }\end{array}$ & Yesl NolNo & Funding & $\begin{array}{l}\# \text { of feasibility studies with positive cost } \\
\text { benefit ratio. }\end{array}$ \\
\hline $\begin{array}{l}\text { NLTSF । } \\
\text { NATMP I NDP }\end{array}$ & YesiNolNo & $\begin{array}{l}\text { Capacity to } \\
\text { deliver }\end{array}$ & $\begin{array}{l}\text { \# of professionally registered personnel } \\
\text { in civil engineering, traffic engineering, } \\
\text { transport economics, town planning, urban } \\
\text { design, and transport planning. }\end{array}$ \\
\hline
\end{tabular}

Source: Own construction from NLTSF, NATMAP and NDP. 
and planning. The NLTSF provides for the implementation of the above on a more detailed level and the IUDF provides holistic overarching framework and levers for policy reforms in key areas that affect urban development, spatial transformation and alignment.

\section{CONCLUSIONS}

The focus of these strategic instruments represents different focuses and timelines although all of them are important building blocks in the development of democracy, addressing the imbalances of the past and the challenges within all spheres of governments, institutions and sectors.

\section{REFERENCES}

[1] National Department of Transport, National Land Transport Strategic Framework for South Africa (2006-2011). Departmental Publication, Pretoria, South Africa, 2006.

[2] Department of Transport, National Land Transport Strategic Framework. Final Draft. Government Gazette Notice 823 of 2015. Government Printer, Pretoria.

[3] Office of the Presidency, National Development Plan 2030. Executive Summary. National Planning Commission. Office of the Presidency. Departmental publication, Pretoria, available at www.thepresidency.gov.za, 2012.

[4] Department of Transport, National Transport Master Plan (NATMAP 2050). Departmental publication, Pretoria, available at www.transport.gov.za, 2011.

[5] Department of Cooperative Governance and Traditional Affairs (COGTA), Draft Integrated Urban Development Framework. Departmental Publication, Pretoria, 2014.

[6] Dressler, S., Strategy, Organisation \& Performance: From Basics to Best Practices, Universal Publishers: Boca Raton, FL, 2004.

[7] Haberberg, A. \& Rieple, A., Strategic Management: Theory and Application, Oxford University Press: Oxford, 2007.

[8] Parnell, J.A., Fundamentals of Strategic Management, SAGE Publications: New York, 2013.

[9] David, F.R., Strategic Management Concepts and Cases, 13th ed., Prentice Hall: CA, 2010.

[10] Council for Scientific and Industrial Research (CSIR), Review of International Case Studies in Metropolitan Strategic Planning, eds. H. Goss \& E. Van Huyssteen, Project Publication BOS67, Pretoria, San Francisco, 2004.

[11] Schoeman, C.B., Intermodal transportation perspectives in South Africa: A case study of its application within the Gauteng Province and lessons learned for other metropolitan areas. Urban Transport XX. 2014, ed. C.A. Brebbia, WIT Press: The Algarve, Portugal.

[12] Sussman, J.M. \& Sgouridis, S., ESD Symposium: Regional Strategic Transportation Planning as a CLIOS, Massachusetts Institute of Technology: Cambridge, MA, 2004.

[13] Robinson, P., Future, Change and Choices. Strategic Planning Methods for Built Environment Professionals, Osborne Porter Literary Services: Westville, Durban, RSA, 2009.

[14] Thompson, A.A. \& Strickland, A.J., Strategic Management: Concepts and Cases. Irwin McGraw-Hill: New York, 1998.

[15] Jeston, J. \& Nelis, J., Management by Process. A Roadmap to Sustainable Business Process Management, Elsevier Ltd.: Burlington, MA, 2008. 
[16] Litman, T., Planning Principles and Practices, Victoria Transport Policy Institute, Canada, available at www.vtpi.org, 2013.

[17] Office of the Presidency, National Planning Commission Diagnostic Report. Departmental Publication, available at www.thepresidency.gov.za, 2011.

[18] Zarenda, H., South Africa's National Development Plan and its implications for regional development, Working Paper of the Trade Law Centre, Stellenbosch, RSA, 2013.

[19] Vna Nieuwkerk, A., South Africa's National Development Plan and Its Foreign PolicyExploring the Interface, WITS School of Governance, Johannesburg, 2014.

[20] Department of Transport, National Transport Master Plan 2050-Synopsis Update, Final Report, Departmental Document, Pretoria, 2015.

[21] South Africa Government, National Infrastructure Plan. Presidential Infrastructure Coordination Commission, Office of the Presidency, Pretoria, 2012.

[22] Office of the Presidency, Development Bank of Southern Africa-State of The State of South Africa's Economic Infrastructure: opportunities and challenges. Published by Development Planning Division, Development Bank of Southern Africa, Halfway House, South Africa, 2012.

[23] Department of Transport, National Land Transport Act (NLTA) Act 5 of 2009, Government Printer, Pretoria, 2009.

[24] Department of Transport, Public Transport Strategy and Action Plan, Departmental Publication, Pretoria, 2006.

[25] Department of Transport, Draft Scholar Transport Policy, Departmental Publication, Pretoria, 2012. 